Leszek Drong*

\title{
Northern Reticence: Articulating a Culture of Silence in Northern Ireland
}

\author{
DOI: http://dx.doi.org/10.12775/LC.2020.043
}

Everybody is communicating in secret. Everybody is speaking in silence.

(Keenan 2019: 237)

ronically, and paradoxically, too, what I want to discuss here - "a culture of silence" - has been widely publicised, and often talked about - by many loquacious individuals. It seems that any discussion of silence is fraught with such paradoxes. The theme for this essay comes from a poem by Seamus Heaney, a poem that came out in his 1975 North collection. The poem is called "Whatever You Say, Say Nothing". I want to quote its third part, which yields an image of Northern Irish society prior to and during the Troubles. What comes to the fore in Heaney's description is an injunction to preserve a conspiracy of silence imposed on society by paramilitary organizations, especially by the Irish Republican Army. The republicans demanded that their members never disclose any information about their organization or about their membership (and thus their actual identity) to people outside the inner circle, not even to their own families. The republican code of silence constituted a supreme law, trumping any other obligations and commitments, very much like the Sicilian omerta or the secret codes of loyalty within the Catholic Church which prevent the clergy from talking openly about sexual harassment or the paedophiles in their midst.

\footnotetext{
* Associate professor in the Institute of Literary Studies at the University of Silesia in Katowice. His primary interest is in Irish cultural studies; he has also published on rhetoric, American pragmatism and literary theory.

E-mail: drong@us.edu.pl | ORCID: 0000-0001-8395-013X.
} 
from "Whatever You Say, Say Nothing"

III

"Religion's never mentioned here", of course.

"You know them by their eyes," and hold your tongue.

"One side's as bad as the other," never worse.

Christ, it's near time that some small leak was sprung

In the great dykes the Dutchman made

To dam the dangerous tide that followed Seamus.

Yet for all this art and sedentary trade

I am incapable. The famous

Northern reticence, the tight gag of place

And times: yes, yes. Of the "wee six" I sing

Where to be saved you only must save face

And whatever you say, you say nothing.

Smoke-signals are loud-mouthed compared with us:

Manoeuvrings to find out name and school,

Subtle discrimination by addresses

With hardly an exception to the rule

That Norman, Ken and Sidney signalled Prod

And Seamus (call me Sean) was sure-fire Pape.

Oland of password, handgrip, wink and nod,

Of open minds as open as a trap,

Where tongues lie coiled, as under flames lie wicks,

Where half of us, as in a wooden horse

Were cabin'd and confined like wily Greeks,

Besieged within the siege, whispering morse.

(Heaney 1998: 132-133; emphases mine)

If Northern Irish literature has a claim to cultural distinctiveness (as a regional literature; i.e. as a minor literature distinct from Irish literature, and certainly distinct from British literature), the claim lies in its open and unconditional embracement of history and reality. This is not to be confused with a simple adherence to the protocols of realism; what I mean is that literary works produced by Northern Irish writers over the last hundred years have never shied away from confronting social, political and historical issues relevant to the North of Ireland. Likewise, Heaney, in this famous poem, braves the waves and speaks at length about some of the most painful taboos in Northern Ireland. What is particularly inspiring here is that he can think of several cunning ways of speaking about silence and denial. To do so he uses ellipsis, understatement, euphemism and allusion: all those figures imply silence without losing their own sonority, that is, as figures of speech they are associated with oral delivery. The paradox of bringing silence and denial to our attention by means of vocal language will recur, in my discussion, in the context of the Boston tapes recorded by the former IRA members who worked hand in hand with Gerry Adams in the early 1970s.

It is worth bearing in mind that, while accusing the people who live in Northern Ireland (including himself, "the artful voyeur" from another famous poem, "Punishment") of remaining passive and reticent, Heaney describes BOTH major communities in Northern Ireland, and only towards the end of part III does he focus exclusively on Irish nationalists. My argument about a culture of silence in Northern Ireland, in turn, will be confined, right 
from the beginning, to the nationalist community because I want to make claims concerning silence and power, relating to how Gerry Adams has performed as a social and political agent within that community. Adams has also become a cultural signifier of sorts, which is perhaps best attested by a recent play by David Ireland, Cyprus Avenue (2016), in which Eric, an aging Loyalist in East Belfast, hallucinates about Adams being reincarnated - while still alive! - within the little body (the glasses, the beard and all) of Eric's five-week-old granddaughter. Adams's stature was seriously shaken a few years ago when several prominent republicans accused him publicly of being their OC (officer commanding) in the ranks of the PIRA (the Provisional Irish Republican Army) at the beginning of the 1970s. In fact, Dolours Price insisted that Adams was in charge of the task force responsible for abducting and then executing Jean McConville, one of the disappeared, a euphemism commonly used to refer to the informers (or those who were accused of being informers) killed by the IRA and then buried usually near the Irish border, in undisclosed locations.

"Whatever you say, say nothing", the phrase that Heaney chooses as the title of his poem, comes from the Green Book, a training and induction manual issued by the IRA (or the "RA, the "I" is often silent) to new volunteers. Incidentally, The Green Book makes its appearance in For the Good Times (2019), the latest novel by David Keenan, a Tarantino-like rendition of the 1970s Belfast from the perspective of an IRA foot soldier. Seamus Heaney, in his poem, not only borrows the phrase "Whatever you say, say nothing" from the Green Book but also elaborates on it, in defiance of the proscription. In a recent work, which reports on the Jean McConville investigation and the history of the PIRA up till the present day, Patrick Radden Keefe ironically clips Heaney's title and leaves only the final part; his own investigative project is called Say Nothing. Keefe's focus is on the Boston tapes and the revelations concerning the murder of Jean McConville. The confessions of former IRA members recorded by the scholars from the Boston College are shocking and seriously ground-breaking for two reasons. First of all, they finally break the republican code of silence (Keefe 2018: 342) concerning certain events and crimes perpetrated by high-ranking members of the IRA. Secondly, the confessions strike at the credibility of Gerry Adams, the republican icon in the island of Ireland and in the USA, one of the most important architects and guarantors of the Good Friday Agreement. At least two prominent IRA members, Dolours Price and Brendan Hughes, claim in an interview that Adams was their Officer Commanding, and a leading figure in the IRA in Belfast at the height of the Troubles in the 1970s. They put him in charge of some of the most spectacular (and most violent) operations conducted by the IRA at that time, although apparently Adams was never a person to directly pull the trigger on the ground.

Keefe's complex, very well researched book is mostly concerned with answering the question who eventually pulled the trigger on Jean $\mathrm{McConville}^{1}$. Still, what emerges from his in-depth discussion of McConville's life and abduction, on the one hand, and the Price sisters' careers in the Provisional IRA and then their imprisonment and growing disillusionment with the politics of Sinn Fein, on the other, is a deterioration of the republican ethos made manifest by the embarrassing facts which have transpired about Gerry Adams

1 Keefe's narrative is carefully and copiously documented. There is also an earlier fictional rendition of the events and circumstances connected with Jean McConville's abduction and murder: White Sand by Simon Kerr (2014). 
and his family. The person who truly personifies the republican ethos, including the IRA's code of silence, is Dolours Price: in 1973, when arrested almost red-handed immediately after the explosions in London caused by car-bombs, she says, pretty much like Shakespeare's Cordelia, "I have nothing to say" (Keefe 2018: 53). Thirty years later, however, and several years after the Good Friday Agreement, she is so scandalised by what happened to the people who had ordered her to plant the bombs in those cars in London that she wants to break the silence. What she cannot understand is how people like Gerry Adams can possibly refuse to take pride in their republican ideals and in pursuing their agenda during the Troubles.

Heaney's poem that I quoted at the beginning is one of the earliest literary representations of the social and political predicament connected with the republican conspiracy of silence. Eviatar Zerubavel, in his work The Elephant in the Room: Silence and Denial in Everyday Life (2006), claims that a conspiracy of silence involves "discretion on the part of the non-producer of the information as well as inattention on the part of its non-consumers" (2006: 48). That is exactly the sort of situation described in Reading in the Dark by Seamus Deane. The novel was published in 1996 but it goes back to the pre-Troubles period: the earliest episodes are set in Derry immediately following WWII. Deane's novel abounds in silences and failures in communication (elsewhere, in my in-depth discussion of the novel, I identify ellipsis as a rhetorical principle of Reading in the Dark - see Drong 2019: 146) and, at the same time, it highlights the status of informers in the local community. No one is allowed to speak about certain aspects of the past; their collective memory is distorted because of the IRA and their crimes (i.e., the mistakes they made). Eventually, the narrator's mother falls completely silent as a result of trauma (caused by compunctions) but it is the absence of communication between children and parents that is particularly painful there. The insurmountable crisis of articulation and emotional interaction in the narrator's family is a side-effect of the republican culture of silence and secrecy. Liam Harte describes this culture in terms of "an aphonia conditioned by the ideologies of both unionism and nationalism” (2000: 155). By turning the history of his family's taciturnity into a narrative, the son inadvertently becomes an informer (Kiberd 2017: 408) in the eyes of his community. He seeks - as Harte claims - "an effective voice, a serviceable name, a recuperative history, an authentic identity" (2000:157) but those will come at the price of being alienated from the conspiracy: as a silence breaker (see Zerubavel 2006: 74) he generates resentment even in his own mother and, as a consequence, he must leave home.

While Deane's narrator is uncharacteristically eloquent for a member of the nationalist community in Northern Ireland (his aunt Katie being another exception), Deane himself remains silent about many painful issues concerning his hometown. In his semiautobiographical novel, there is virtually no mention of the unionist community, a political gesture of silencing a sizeable population equivalent to the obliteration of the first part of the name of the city (Londonderry) on many road signs in Northern Ireland. This is what Keith Grant-Davies calls a visual manifestation of silence for a rhetorical effect (2013: 5). Republicans would do that to emphasize their claim to the entire city, based on its Irish origins and their prevalence there. Still, what many unionists see and hear, when they encounter the old, alternative or truncated version of the name of the city (depending on how you view its politics and history), is silence fraught with violence. 
Quite outspoken about violence during the Troubles is For the Good Times (2019) by David Keenan. Its narrator, young Samuel McMahon, or Xamuel, as he envisions himself probably under the influence of his favourite comics combined with Blake's poetry, reminisces about his "happy days" as an IRA foot soldier while doing time in the Maze prison. What he experiences resembles a massive hallucination, a form of self-delusion, which results in his denial of reality. This, in turn, leads him to reflect, in retrospect, on the collective denial (see Zerubavel 2006: 14) of the entire Northern Irish society during the Troubles, especially in the 1970s. Here is how he explains the connection between lying, denial and silence in Northern Ireland, especially among the republicans:

It was a web of lies we were all caught in. It's the default position of all the Irish. If in doubt, lie; if asked, make it up; if questioned, deny it. It had been drilled into us since we were kids, tell them fucking nothing, but it meant that every single relationship in your life was up for questioning. It meant that there were things you wouldn't even tell your own reflection. (Keenan 2019:216)

Sammy's massive hallucination and descent into numbed violence are directly linked to the republican conspiracy of silence, which produced a comic book fantasy of the Troubles in West Belfast (and in Ardoyne), completely detached from the realities of moral existence. In a culture of silence you do not ask yourself fundamental axiological questions. That is why a novel like Keenan's, by exposing its deficiencies, has earned considerable acclaim from literary critics and other writers alike. Eoin McNamee, concluding his review for The Irish Times, called it "visionary fiction, occult in intent, brilliant in execution. The North's bequest of the unsaid and the never-to-be-said are beginning to be addressed, with Keenan among salutary others finding the words" (McNamee 2019). Saying the unsaid and the unsayable is a particularly important trope that I want to explore further on in this essay.

Out of the recent works of fiction that explore what has been left unsaid (i.e. truth recovery) in Northern Ireland post Good Friday Agreement, David Park's The Truth Commissioner (2009) brings together a number of issues relevant to the central theme of my essay. In fact, the novel begins with the abduction and murder of a teenager who represents an exemplary case of the disappeared in Northern Ireland. Connor Walshe, quite like Jean McConville in real life, is accused of being an informer, lifted off the street and interrogated. When he tries to escape, a fight ensues and the boy is accidentally shot dead. His body is buried in the middle of nowhere and it is not until several decades later that his family recover his remains. Another episode resonates with the reader familiar with the plight of the 16 Northern Irish disappeared: during a Truth Commission session Connor's voice accuses his police handlers of blackmailing him and putting his life at risk. The voice is recorded on tape and played many years after the boy had been murdered (Park 2009: 327-328). It is a voice from (beyond) the grave, a voice from the heart of silence. Connor's is not only an accusation of the RUC now transformed into the PSNI; his case, and his body finally disinterred in the last episode of the novel, is a breach in the republican conspiracy of silence responsible for the deaths of the Northern Irish disappeared ${ }^{2}$. In fact, the prosopopoeic disruption of the silent social consensus in Park's utopian narrative runs parallel to real-life

2 For an interesting example of a visual breach of the conspiracy of silence over the disappeared in Northern Ireland see David Farrell's photography, especially The Disappeared series (Farrell, not dated). I am grateful to Wesley Hutchinson who brought Farrell's photography to my attention. See Hutchinson 2018: 366-372. 
developments documented in Ed Moloney's book, Voices from the Grave (2010), published two years following The Truth Commissioner.

Moloney's book is a by-product of the Belfast Project, an unprecedented attempt to rescue a substantial part of oral history of Northern Ireland and store it in a safe location in the United States. The project was initiated in 2001, a few years after the Good Friday Agreement, by a group of scholars from Boston College who aimed at collecting honest, uncensored testimonies from both republican and loyalist paramilitaries active during the Troubles. The idea was to obtain a balanced picture of the conflict from the insiders' point of view, one that could be consulted by the future generations of students of history. The tapes with the interviews, conducted by researchers (Wilson McArthur and Anthony McIntyre - see "What Are the Boston Tapes?" 2017) who had been involved in the Troubles themselves and thus found it easier to win the trust of the interviewees, were stored in the vault of the John J. Burns Library of Boston College ${ }^{3}$. The tapes were not meant to be revealed, and then only at the discretion of the project's supervisors, to the students of Boston College until after the death of the interviewees. History proved to be a little more complicated.

Because the conspiracy of silence in Northern Ireland, Heaney's "tight gag of time and place", has never been officially lifted, all the people involved in the Belfast Project were well aware of its transgressive nature. Some of the confessions made on tape struck at the republican dogmas and idols, especially at Gerry Adams, who has consistently denied ever being involved in the IRA. Acknowledging officially an involvement like that might ruin his political career, not least because it has been built on many lies and denial. Still, his role in the organization and a high rank in the Belfast structures of the Provisional IRA have been an open secret (Little 2019), what Zerubavel describes in terms of an elephant-in-the-room situation in Northern Ireland. That is why finally unveiling this elephant (2006: 63-66) and making people painfully aware that they had been ignoring an obvious truth was not an easy thing to do and originally, especially in Northern Ireland, it met with considerable resistance.

One of the people who decided to tell the truth about Adams's pivotal role in the kidnapping and executing of Jean McConville was Brendan Hughes. At the time of making his recording he knew that breaking the silence was tantamount to a prison sentence (Moloney 2010: 293) but he was also scandalised by the IRA's hypocrisy and the degradation of the republican ethos reflected in the number of informers who infiltrated the movement (Moloney 2010: 283-284). On his recording, Hughes, an iconic figure within the PIRA and a hero of the first hunger strike in the Maze in 1980, is quite vocal about the power bid behind the code of silence imposed on the republicans in Northern Ireland: “...there's a Republican repression of anyone who dares to object or who dares to question the leadership line... we've been told all along that this is not a leadership led movement, this is a movement led by the rank and file. That's a load of bollocks. This is a movement led by the nose by a leadership that refuses to let go and anyone who objects to it, anyone who has an alternative, is either ridiculed, degraded, shot or put out of the game altogether" (Moloney 2010: 288). Those words sound prophetic concerning Dolours Price who, in her interview for the Belfast Project, accused Gerry Adams of giving her a direct order to abduct Jean

\footnotetext{
3 For a detailed account of the Belfast Project, see Moloney 2010: 1-9.
} 
McConville, a mother of ten, and then drive her across the border to be executed and buried in an undisclosed location. Keefe, in his recent book on the McConville investigation and the Belfast Project, claims that all the evidence points to Dolours's sister, Marian, being the actual executioner.

Dolours Price was another republican interviewed in the early 2000s for the Belfast Project. Interestingly, she had already hinted, in some other interviews published in the Republic of Ireland, and later used to subpoena the tapes from Boston College, that Adams was her OC and that his involvement in the IRA was unquestionable (Morris 2010). Adams and his political entourage tried to downplay Price's accusations, emphasising her alcohol and drug abuse. They thought the problem would disappear with Price's death in 2013 but then it turned out that it was possible to retrieve the tapes from the vault in the Burns Library and use them in Northern Ireland as evidence. Gerry Adams faced criminal charges in connection with the murder of Jean McConville. Even though, following his arrest in 2014, he was released (there was not enough evidence to convict him), Adams eventually decided to step down as the leader of Sinn Fein in 2018. Suddenly in Northern Ireland everybody saw not just one elephant but several others: it turned out that Adams ignored the fact that his brother Liam, also a member of Sinn Fein, was a paedophile, who molested his own daughter, and then, when this came to light, Gerry, a devout Catholic, allowed him to work with other children for many years (Carroll 2019). Silence and denial proved to be, at least in his case, a cul-de-sac.

In more general terms, it seems that the republicans in Northern Ireland sought to develop a culture of silence and secrecy to exercise power and control over their own community. Gerry Adams has become a leading political figure by consistently practising denial, camouflage, and a kind of "sealed-lips" strategy. In the long run, however, the exercise of power through silence has led to a disintegration of the republican community, rather than to its integration, as, apparently, a conspiracy of silence has a disturbing effect and generates resentment (and sooner or later it provokes breaking the silence). The nationalist conspiracy of silence has, over the years, triggered a number of literary (fictional) confessions as well as a tendency to parade one's own (non-fictional) republican agenda; if not directly, in front of the British authorities in Northern Ireland, then at least as a badge of honour for the international press or for American scholars. During the Troubles, even though the republican code of silence was enforced by the threat of death, it bred an opposing effect, that of the desire to confess ${ }^{4}$, to report, to inform, to BOAST of one's performance as a terrorist: it was already in the early 1970s that Dolours Price gave a series of interviews to foreign reporters (encrusted with provocative photographs of herself as a young outlaw in Vanity Fair). This paradoxical effect of collective silencing may also account for the number of informers ("touts") in the ranks of the IRA during the Troubles. Those included Gerry Adams's personal chauffeur (not outed until 2008!) and Alfredo Scappaticci, the head of the so-called Nutting Squad, responsible for... hunting and executing informers (Keefe 2018: 281-282). An injunction to keep silent appears to breed only more disquietude.

\footnotetext{
${ }^{4}$ One thinks of Michel Foucault's History of Sexuality...
} 


\section{Bibliography}

Carroll, Rory 2019. "Liam Adams, brother of ex-Sinn Féin leader Gerry Adams, dies". The Guardian, 25 February 2019. On-line: https://www.theguardian.com/uk-news/2019/feb/25/liamadams-brother-sinn-fein-leader-gerry-adams-dies [24.09.2019].

Deane, Seamus 1997. Reading in the Dark. London: Vintage.

Drong, Leszek 2019. Tropy konfliktu. Retoryka pamięci kulturowej we wspótczesnej powieści pótnocnoirlandzkiej. Katowice: Wydawnictwo Uniwersytetu Śląskiego.

Farrell, David n.d. "The Intangible Presence of Absence". On-line: http://davidfarrell.org/landscape-as-witness/the-disappeared/intro [14.04.2019].

Grant-Davies, Keith 2013. "Rhetorical Uses of Silence and Spaces". In: Leslie Boldt [\&] Corrado Federici [\&] Ernesto Virgulti (eds.). Silence and the Silenced: Interdisciplinary Perspectives. New York: Peter Lang. 1-11.

Harte, Liam 2000. "History Lessons: Postcolonialism and Seamus Deane's Reading in the Dark". Irish University Review 30, 1: 149-162.

Hutchinson, Wesley 2018. “The Northern Ireland Troubles: What Was There to Photograph?”. Przeglad Kulturoznawczy 37, 3: 365-380.

Ireland, David 2016. Cyprus Avenue. London: Bloomsbury Methuen Drama.

Keefe, Patrick Radden 2018. Say Nothing: A True Story of Murder and Memory in Northern Ireland. London: William Collins.

Keenan, David 2019. For the Good Times. London: Faber \& Faber.

Kerr, Simon 2014. White Sand. Black Flag.

Kiberd, Declan 2017. After Ireland: Writing the Nation from Beckett to the Present. London: Head of Zeus.

Little, Ivan 2019. "Gerry Adams sent me to US to buy rifles for the Provos: ex-top IRA man". The Belfast Telegraph, 24 September 2019. On-line: https://www.belfasttelegraph.co.uk/news/ northern-ireland/ [24.09.2019].

McNamee, Ian 2019. “Troubling Truths". The Irish Times, 26 January 2019. On-line: https://www. irishtimes.com/culture/books/for-the-good-times-by-david-keenan-review-troublingtruths-1.3760048 [24.09.2019].

Moloney, Ed 2010. Voices from the Grave: Two Men's War in Ireland. London: Faber \& Faber.

Morris, Allison 2010. "Irish News Interview with Dolours Price”. The Irish News, 18 February 2010, on-line.

Park, David 2009. The Truth Commissioner. London, New Delhi, New York and Sydney: Bloomsbury.

"What Are the Boston Tapes?" 2017. BBC News, 17 November 2017. https://www.bbc.com/news/ uk-northern-ireland-27238797. [14.04.2019].

Zerubavel, Eviatar 2006. The Elephant in the Room: Silence and Denial in Everyday Life. Oxford: Oxford University Press. 